\title{
PENGARUH CITRA MEREK TERHADAP PERSEPSI CITARASA
}

\section{E. Rindangi Putri Hermanto \& Haryanto Fadholan Rosyid}

Fakultas Psikologi Universitas Gadjah M ada

\begin{abstract}
This research investigated the effect of brand image on taste perception. The hypothesis of this research was that brand images would affect taste perception. It was also hypothesized that more qualified brand would result in more positive taste perception than less qualified brand. Product used in this research was mineral water. Two brands chosen for this research were A-one which represent more qualified brand, and A-two which represent less qualified brand (compared to A-one). Apart from these two brands, a non-branded package was also used.

The samples ( $N=60$ ) were undergraduate student of the Faculty of Psychology, a State Own University in Jogyakarta, who volunteered as research subjects. The samples were assigned to evaluate the taste of mineral water served in the three different brand packages. A taste perception scale was employed to collect data through a counter-balance experimental design method. Experimental method with counter-balance design was conducted to ensure that the different in taste perception was the result of different brand images.

Result revealed that brand image had effect on taste perception ( $F=12,824$, $p<0,01)$. Branded package elicited positive response more than non-branded package. Thus, it causes more positive taste perception. Different result was obtained for more qualified brand and less qualified brand. There was no difference between more qualified brand and less qualified brand on taste perception. This study concluded, due to similarity of the brands character, samples intend to have the same taste perception on the brands.
\end{abstract}

Keywords: taste perception, brand images

\section{Pengantar}

Pada umumnya, konsumen akan mengambil keputusan untuk membeli suatu produk berdasar pada penilaian yang dilakukannya terhadap kualitas yang dimiliki oleh produk tersebut. Dalam melakukan penilaian, konsumen akan mempergunakan berbagai stimuli yang ditangkap oleh alat inderanya sebagai bahan pertimbangan. Stimuli seperti warna, bau, bentuk, bunyi, rasa, dan tekstur dapat berfungsi sebagai 
penanda bagi kualitas produk. Khusus untuk produk makanan dan minuman, reseptor rasa yang dimiliki manumur memainkan peran yang penting dalam penilaian terhadap kualitas yang dimiliki oleh sesuatu produk (Wells \& Prensky, 1996).

Penilaian konsumen terhadap berbagai produk makanan dan minuman sangat dipengaruhi oleh persepsi citarasa (Wells \& Prensky, 1996). Selama makan atau minum, individu akan melakukan persepsi terhadap citarasa. Persepsi citarasa tidak diukur dari rasanya saja, namun dipengaruhi juga oleh aroma, cara penyajian yang tepat, sampai suasana saat menikmatinya (www.kompas.co.id).

Gibson (dalam Sekuler \& Blake, 1990) berpendapat selama makan atau minum, individu akan melakukan persepsi terhadap citarasa. Ketika makan atau minum, individu mempelajari lebih dari sekedar rasa substansi. Hal-hal yang diperoleh selama individu makan dan minum antara lain meliputi penilaian terhadap suhu, tekstur, dan konsistensi makanan. Semua aspek tersebut pada akhirnya akan membentuk sensasi kompleks yang disebut sebagai citarasa (Gibson dalam Sekuler \& Blake, 1990).

Citarasa adalah penilaian terhadap sensasi kompleks yang diperoleh selama individu melakukan pengecapan dan berkaitan erat dengan penerimaan individu terhadap bahan pangan. Jadi dapat disimpulkan bahwa selama individu melakukan pengecapan, individu akan mempersepsi sensasi kompleks yang disebut citarasa.

Citarasa mencakup banyak faktor, seperti substansi, aroma, tekstur, suhu, warna, dan suara yang ditimbulkan pada saat substansi dikunyah (Schiffman, 1990). Delwiche (dalam Kharismahayati, 2006) menyatakan bahwa persepsi citarasa merupakan hasil interaksi antara aspek: rasa, bau atau aroma, iritasi akibat persinggungan dengan bahan kimia, suhu, warna, tekstur dan bunyi yang dihasilkan saat makanan dikunyah. Dalam penelitian ini aspek iritasi akibat persinggungan dengan bahan kimia, suhu, dan bunyi tidak disertakan karena produk yang digunakan dalam penelitian tidak memiliki kedua aspek tersebut. Selain itu, ditambahkan aspek berupa penilaian penilaian pengaruh produk terhadap kesehatan dan penilaian keseluruhan terhadap citarasa (Sekuler \& Blake, 1990), karena persepsi citarasa berkaitan erat dengan penerimaan terhadap bahan pangan.

Pengalaman rasa juga merupakan hasil dari pengharapan yang disebabkan oleh apa yang dilihat individu (Norris dalam Kharismahayati, 2006). Persepsi citarasa bukan merupakan kriteria obyektif, tetapi berkaitan erat dengan citra merek yang ada di benak konsumen (Sulaksana, 2003). 
Merek memiliki peran yang dominan dalam pengambilan keputusan pemilihan produk, karena merek merupakan isyarat (cues) dengan jangkauan luas yang memiliki dampak bagi bermacam-macam atribut (Purohit \& Srivastava, 2001). M isal merek J.Co dan Starbuck yang sering diatribusikan dengan produk lifestyle bagi kalangan menengah ke atas (Hendriani, 2006) atau black coffee (kopi pahit) yang diatribusikan dengan kalangan pekerja atau buruh.

Citra merek adalah suatu kumpulan persepsi lengkap dari seorang individu terhadap suatu jenis produk, toko, pengecer, dan perusahaan secara khusus yang mana akan mempengaruhi persepsi konsumen akan kualitas suatu produk. Enam variabel utama yang membentuk citra merek, yaitu produk itu sendiri, kemasan, nama merek, harga merek, iklan dan promosi, dan distribusi.

Citra suatu merek selalu berhubungan dengan sikap. Sikap positif konsumen terhadap sebuah merek lebih mudah mengarahkannya untuk membeli merek dan produk tersebut. Karena itu, tujuan utama strategi pemasaran, baik melalui iklan, publikasi maupun cara tradisional adalah mengembangkan citra positif terhadap merek (Ismarrahmini \& Brotoharsojo, 2005).

Akibatnya, tidak mengherankan jika perusahaan-perusahaan menghabiskan jutaan dolar untuk membangun citra merek dengan bermacam-macam cara. Citra akan memberi faktor kunci dalam pembedaan sebuah perusahaan satu dengan perusahaan sejenis yang lain (Schiffman \& Kanuk, 2004). Citra merek adalah apa yang akan konsumen lihat dan rasakan ketika nama dari suatu merek disebut. Kotler (1997) menyatakan bahwa citra ini akan positif jika konsumen akan memberikan kesan yang menyenangkan ketika nama merek ini disebut. Pengetahuan konsumen tentang merek ini sangat tinggi sehingga akan mempengaruhi proses pengambilan keputusan.

Citra merek yang kuat dapat mempengaruhi citarasa suatu produk makanan atau minuman. Oleh karena itu faktor citarasa memperoleh banyak perhatian dari produsen produk makanan. Meskipun demikian, persepsi citarasa bukan merupakan kriteria objektif, tetapi berkaitan erat dengan citra merek yang ada di dalam benak konsumen (Sulaksana, 2003). Pengalaman rasa juga merupakan hasil dari pengharapan yang disebabkan oleh apa yang dilihat oleh individu (Kharismahayati, 2006).

Persepsi positif atau negatif terhadap citra merek dapat mempengaruhi persepsi individu terhadap citarasa. Hal ini terlihat dari menjamurnya coffee shop yang telah menjadi gaya hidup baru bagi kaum muda Yogyakarta. Beragam pilihan ditawarkan, dari coffee shop mewah nan mahal sampai warung kopi lokal dengan harga murah meriah (Taniardi, 2006). Kopi yang disajikan pun menjadi berbeda 
citarasanya saat dihidangkan di coffee shop mewah yang eksklusif, dan harganya tentu mahal, dibandingkan yang disajikan di warung kopi sederhana dengan harga murah meriah.

Mundayat menjelaskan coffee shop menunjukkan kelas, tergantung pada komunitas dan harga yang ditawarkan. Hal ini lebih dikarenakan adanya segmentasi. Warung pun merupakan bentuk lain dari coffee shop, hanya saja konsumennya berbeda (Taniardi, 2006).

Thumin (dalam Solso, Johnson, \& Beal, 1998) menjelaskan tidak ada hubungan antara kemampuan mengidentifikasi merek dan rasa cola (sejenis minuman ringan) dengan jumlah konsumsi cola rata-rata dalam satu minggu. Lebih lanjut menurut Thumin (dalam Solso, Johnson, \& Beal, 1998) menemukan bahwa orang-orang tidak lebih baik dalam mengidentifikasi merek yang biasa mereka konsumsi dengan merek lain. Hal ini menunjukkan, sebenarnya konsumen sulit membedakan rasa merek cola satu dengan merek yang lain. Citra mereklah yang membuat konsumen memutuskan memilih Coca-Cola, Pepsi Cola, atau Royal Crown.

Van Osselaer \& Janiszewski (2001) menemukan bahwa muffin (sejenis kue) yang menggunakan bahan-bahan bermerek dipersepsi lebih terasa, rasa coklatnya daripada muffin yang tidak menggunakan bahan-bahan bermerek. Semakin terasa coklatnya maka semakin positif citarasa muffin tersebut.

Widyaningrum (1997) menyatakan perilaku konsumen yang hanya memilih merek tertentu dapat disebabkan menjaga "gengsi", karena mungkin persepsi terhadap citra merek tertentu rendah atau kalah dengan merek lain. Persepsi ini akan terbentuk dengan serangkaian informasi dan atribut yang dikaitkan dengan merek produk tersebut. Informasi ini bisa bersifat intrinsik, yang berkaitan langsung dengan produk tersebut seperti warna, ukuran, rasa, aroma maupun yang sifatnya ekstrinsik seperti harga, kemasan, citra, toko yang menjual, maupun pelayanan yang diberikan dan promosinya. Hal ini dapat terlihat pada produk air minuman dalam kemasan.

Van Osselaer \& Janiszewski (2001) mengemukakan hubungan antara citra merek dan keuntungannya yang dalam hal ini citarasa dapat dijelaskan dengan model HAM dan ANM. Teori tersebut menjelaskan bahwa citra merek adalah isyarat (cues) yang berhubungan erat dengan hasil keluaran yaitu citarasa. Hubungan ini akan semakin kuat setiap kali hubungan terjadi. M isal suatu saat konsumen membeli merek A dan merasa sangat puas terhadap pelayanan dan produknya maka konsumen tersebut akan mempersepsi positif terhadap merek A. Dan persepsi positif ini akan 
semakin menguat setiap kali konsumen tersebut melakukan penggunaan ulang dan merasa puas. Penguatan lain bisa diperoleh dari referensi orang lain bahwa merek $A$ sangat baik.

Berdasar teori pengkondisian klasik Pavlovian, pembelajaran bersyarat memberikan hasil bila suatu stimulus yang dipasangkan dengan stimulus lain memunculkan suatu respon, dan respon ini membantu menghasilkan respon yang sama ketika digunakan sendirian. Dalam konsep eksperimen, jika suatu stimulus tak bersyarat (unconditioned stimulus) menghasilkan suatu respon tak bersyarat (unconditioned response), kemudian stimulus bersyarat (conditioned stimulus) setelah dipasangkan berulang dengan stimulus tak bersyarat akan menghasilkan respon yang sama, atau disebut respon yang dikondisikan (conditioned response) atau respon bersyarat (Apsari, 2006). Dengan demikian persepsi yang baik pada citra merek akan menghasilkan evaluasi yang positif (Schiffman \& Kanuk, 2004; Engel, Blackwell, and Miniard, 1990). Apabila suasana tersebut hadir bersama dengan citarasa, maka citarasa produk tersebut akan dievaluasi positif pula.

Dengan demikian dapat disimpulkan bahwa persepsi citarasa dapat dipengaruhi oleh citra merek. semakin positif citra merek semakin positif citarasa.

\section{Metode}

Penelitian dilakukan di Jogyakarta dengan subyek sebanyak 60 orang mahasiswa Fakultas Psikologi sebuah Universitas milik pemerintah. Data penelitian diperoleh dengan menggunakan skala persepsi citarasa yang dimodifikasi Kharismahayati (2006). Merek yang digunakan dalam penelitian ini adalah merek Aone, A-two, dan tanpa merek. Pemilihan merek berdasarkan pada hasil-hasil penelitian Susanta (2005). Pencatatan waktu dilakukan dengan menggunakan alat stop-watch.

Rancangan eksperimen yang digunakan adalah counte-rbalanced design yang digunakan untuk meningkatkan control dan ketepatan pengukuran (Campbell \& Stanley, 1973). Selain itu, rancangan ini digunakan untuk memastikan bahwa perbedaan citarasa yang terjadi bukan karena perbedaan antar subyek, tetapi karena perlakuan yang diberikan pada subyek. Rancangan eksperimen dapat dilihat pada Tabel 1. 
Tabel 1

Rancangan Penelitian

Pengaruh Citra Merek terhadap Presepsi Citarasa

\begin{tabular}{|c|c|c|c|c|}
\hline & & Urutan 1 & Urutan 2 & Urutan 3 \\
\hline \multirow{6}{*}{$\mathbf{R}$} & K1 & $X_{A-1} 0$ & $\begin{array}{ll}X_{T} & 0\end{array}$ & $X_{A-2} 0$ \\
\hline & K2 & $x_{T} \quad 0$ & $X_{A-1} \quad 0$ & $X_{A-2} 0$ \\
\hline & K3 & $X_{A-2} 0$ & $X_{A-1} 0$ & $x_{T} \quad 0$ \\
\hline & K4 & $X_{A-1} 0$ & $x_{A-2} \quad 0$ & $\begin{array}{ll}x_{T} & 0\end{array}$ \\
\hline & K5 & $X_{A-2} 0$ & $\begin{array}{ll}X_{T} & 0\end{array}$ & $X_{A-1} 0$ \\
\hline & K6 & $\begin{array}{ll}x_{T} & 0\end{array}$ & $X_{A-2} \quad 0$ & $X_{A-1} 0$ \\
\hline
\end{tabular}

Keterangan:
$\mathrm{R} \quad$ : Penugasan
K1 : Kelompok 1
K2 : Kelompok 2
K3 : Kelompok 3
$X_{A-1} \quad$ : Perlakuan berupa minuman bermerek $A$-one
$X_{A-2}$ : Perlakuan berupa minuman bermerek A-two
$X_{T} \quad$ : Perlakuan berupa minuman tidak bermerek
0 : Pengukuran dengan skala persepsi citarasa

Dalam pelaksanaan penelitian, peneliti dibantu oleh tiga orang asisten peneliti yang bertugas menyajikan minuman dan memeriksa kelengkapan pengisian skala subyek. Satu orang asisten peneliti bertanggung jawab terhadap dua kelompok perlakuan.

Penelitian dimulai dengan penjelasan yang diberikan oleh peneliti mengenai tujuan diadakannya penelitian. Peneliti menyampaikan bahwa penelitian ini adalah sebuah survei terhadap jenis-jenis air mineral. Subyek diminta untuk memberikan penilaian terhadap 3 jenis air mineral yang akan disajikan. Kemudian subjek dimintai kesediaannya untuk membantu pelaksanaan penelitian yang akan dilakukan. Setelah itu peneliti akan menjelaskan prosedur pelaksanaan penelitian dan petunjuk teknis pengisian skala.

Subyek dibagi menjadi enam kelompok secara random, yaitu subyek diminta mengambil undian yang bertuliskan angka-angka 1 sampai 6 . Angka-angka itu 
menunjukkan pembagian penugasan yang disesuaikan dengan rancangan eksperimen. Kelompok 1 secara berurutan diberi minuman dengan label merek A-one, minuman tanpa label merek, dan minuman dengan label merek A-two. Kelompok 2 secara berurutan diberi minuman tanpa label merek, minuman dengan label merek A-one, dan minuman dengan label merek A-two. Kelompok 3 secara berurutan diberi minuman dengan label merek A-two, minuman dengan label merek A-one, dan minuman tanpa label merek. Kelompok 4 secara berurutan diberi minuman dengan label merek A-one, minuman dengan label merek A-two, dan minuman tanpa label merek. Kelompok 5 secara berurutan diberi minuman dengan label merek A-two, minuman tanpa label merek, dan minuman dengan label A-one. Kelompok 6 secara berurutan diberi minuman tanpa label merek, minuman dengan label merek A-two, dan minuman dengan label merek A-one. Masing-masing subyek mendapat perlakuan berupa minuman air mineral yang dikemas dalam tiga kemasan yang berbeda. Penugasan berupa penyajian minuman siap saji dengan urutan yang berbeda untuk tiap kelompok.

Setelah didapat 6 kelompok subjek, peneliti membagikan skala persepsi citarasa dan air minum dalam kemasan kemudian subjek diminta mengisi data diri. Minuman disajikan pada subjek sesuai dengan urutan pertama penugasan. Subjek diminta untuk mengamati dan mencicipi minuman yang disajikan sesuai dengan urutan pertama yang ditugaskan pada kelompoknya. Setelah subjek mencicipi minuman yang disajikan, subjek diminta untuk mengisi skala persepsi citarasa sesuai dengan keadaan dirinya yang sebenarnya. Setelah tahap pemberian perlakuan pertama, dilanjutkan dengan memberikan perlakuan yang kedua dan selanjutnya sesuai urutan penugasan. Sesudah pemberian perlakuan, subjek diminta mengisi skala persepsi citarasa.

Dalam setiap perlakuan, subjek diberi waktu selama 10 (sepuluh) menit untuk mengamati dan mencicipi minuman yang disajikan serta mengisi skala persepsi citarasa. Pemberian waktu selama 10 (sepuluh) menit diperkirakan sudah mencukupi bagi subjek untuk memberikan penilaian terhadap minuman yang disajikan. Pertimbangannya adalah bahwa manumur dapat membuat keputusan berdasarkan informasi yang diperoleh indera pengecap dalam waktu 50 (lima puluh) milidetik setelah mencicipi makanan dan minuman (Kharismahayati, 2006).

Setelah selesai mengisi skala ketiga yaitu skala persepsi citarasa, peneliti memberitahukan bahwa sebenarnya ketiga air mineral yang disajikan dan mereka nikmati adalah air mineral yang sama, dan mereknya tidak berbeda. Peneliti juga menyampaikan tujuan sebenarnya dari penelitian yang dilakukan. Setelah 
pengambilan data selesai dan penyampaian informasi mengenai penelitian telah lengkap, subjek diperbolehkan pulang.

\section{Hasil}

1. Deskripsi Subjek Penelitian

Subjek penelitian berjumlah 60 mahasiswa Fakultas Psikologi, sebuah Perguruan Tinggi Negeri di Jogyakarta, datanya dapat dideskripsikan, disusun berdasarkan data identitas yang telah diisi oleh subjek. Dari data tersebut dapat diketahui karakteristik subjek yang lain seperti umur dan jenis kelamin. Berikut ini deskripsi subyek dari data yang diperoleh seperti dalam tabel di bawah ini:

\section{Tabel 2}

Deskripsi Subjek Penelitian berdasar Umur dan Jenis Kelamin

\begin{tabular}{ccccc}
\hline Karakteristik Subjek & Jumlah Subjek & Prosentase & Total \\
\hline \multirow{4}{*}{ Umur } & 17 tahun & 2 & $3,33 \%$ & \\
& 18 tahun & 7 & $11,67 \%$ & \\
& 19 tahun & 14 & $23,33 \%$ & \\
& 20 tahun & 12 & $20 \%$ & 60 \\
& 21 tahun & 12 & $20 \%$ & \\
\hline \multirow{2}{*}{ Jenis } & 22 tahun & 8 & $13,33 \%$ & \\
Kelamin & 23 tahun & 5 & $8,34 \%$ & 60 \\
\hline
\end{tabular}

Tabel menunjukkan bahwa pada kategori umur yang paling banyak dalam subyek ini ialah kisaran antara 19-21 tahun yang mencakup besaran 63,33\%, sementara komposisi pada jenis kelamin terlihat lebih besar porsinya pada kelompok perempuan (81,67\%) sedang kelompok laki-laki hanya 18,33\%. Komposisi ini mencerminkan bahwa subyek duduk di suatu fakultas yang didominasi oleh jenis kelamin perempuan. 


\section{Deskripsi Data Penelitian}

Pada tabel berikutnya ditampilkan gambaran umum mengenai data persepsi citarasa yang diambil dari 60 orang subyek dengan menggunakan alat ukur skala citara persepsi yang dikembangkan oleh Kharismahayati (2006), sebagai mana tersaji dalam Tabel 3 di bawah ini:

Tabel 3

Deskripsi Data Persepsi Citarasa $(\mathrm{N}=60)$

\begin{tabular}{lllll}
\hline & Minimun & Maksimum & Rentang & $\begin{array}{l}\text { Standar } \\
\text { Deviasi }\end{array}$ \\
\hline Hipotetik & 9 & 63 & 54 & 9 \\
Skor persepsi citarasa & 26 & 63 & 37 & 8,00 \\
Merek A-one & 36 & 63 & 27 & 6,82 \\
Merek A-two & 35 & 63 & 28 & 7,33 \\
Tanpa merek & 26 & 63 & 37 & 9,11 \\
\hline
\end{tabular}

\section{Deskripsi Kategorisasi Data}

Sebaran skor persepsi citrasa dapat dilihat pada Tabel 4

Tabel 4

Penyebaran Skor dalam masing-masing Kategori

\begin{tabular}{|c|c|c|c|c|c|c|}
\hline \multirow{2}{*}{ Kategori } & \multicolumn{2}{|c|}{ Merek A-one } & \multicolumn{2}{|c|}{ Merek A-two } & \multicolumn{2}{|c|}{ Tanpa Merek } \\
\hline & Jumlah & $\%$ & Jumlah & $\%$ & Jumlah & $\%$ \\
\hline Sangat rendah & 2 & 3,33 & 2 & 3,33 & 8 & 13,33 \\
\hline Rendah & 11 & 18,33 & 15 & 25 & 20 & 33,33 \\
\hline Sedang & 23 & 38,33 & 24 & 40 & 18 & 30 \\
\hline Tinggi & 18 & 30 & 14 & 23,33 & 8 & 13,33 \\
\hline Sangat Tinggi & 6 & 10 & 5 & 8,33 & 6 & 10 \\
\hline
\end{tabular}

\section{Hasil Uji Prasyarat}

Uji asumsi sebagai prasyarat sebelum melakukan analisis dengan teknik perbandingan analisis varian perlu dilakukan, yaitu uji normalitas sebaran dan uji homogenitas.

a. Hasil Uji Normalitas

Uji normalitas sebaran dilakukan dengan menggunakan teknik statistik one sample Kolmogorov-Smirnov. Kaidah yang digunakan yaitu jika $p>0,05$ maka 
sebaran data tersebut menyerupai bentuk kurve normal, sedangkan jika $p<0,05$ maka sebaran data tersebut tidak menyerupai bentuk kurve normal.

Analisis data menunjukkan bahwa untuk merek $A$-one nilai $Z=0,628$ dengan $p=0,825(p>0,05)$, untuk merek $A$-two $Z=0,538$ dengan $p=0,934(p>0,05)$, dan untuk minuman tanpa label merek $Z=0,682$ dengan $p=0,741(p>0,06)$. Berdasarkan hasil analisis ini, maka dapat dikatakan bahwa sebaran data ketiga variabel penelitian tersebut mengikuti bentuk kurve normal.

b. Hasil Uji Homogenitas

Uji homogenitas terhadap faktor antar subyek dilakukan dengan Levene's Test. Kaidah yang digunakan dalam uji ini adalah data homogen apabila $p>0,05$ sedangkan bila $p<0,05$ maka sebaran data tersebut tidak homogen.

Penghitungan yang dilakukan menghasilkan $p=0,57$ untuk kemasan dengan label merek A-one, $p=0,232$ untuk kemasan dengan label merek A-two, dan $p=$ 0,673 untuk kemasan tanpa label merek. Hasil ini menunjukkan bahwa sebaran data dalam penelitian ini adalah homogen.

\section{Hasil Uji Hipotesis Penelitian}

Setelah terpenuhinya uji asumsi maka selanjutnya dilakukan analisis uji hipotesis. Untuk melakukan analisis tersebut, digunakan teknik statistic analisis varian (Field, 2000). Rangkuman hasil analisis varian dapat dilihat pada Tabel 5.

Tabel 5

Rangkuman Hasil Analisis Varian

\begin{tabular}{llllllll}
\hline \multicolumn{2}{c}{ Sumber Variasi } & JK & Db & MK & F & p & $\begin{array}{l}\text { Eta } \\
\text { kuadrat }\end{array}$ \\
\hline \multirow{2}{*}{ Dalam } & Merek & 648,433 & 2 & 324,217 & 12,824 & $\varangle 0,001$ & 0,192 \\
subyek & Merek* Urutan & 156,433 & 10 & 15,643 & 0,619 & 0,795 & 0,054 \\
& Error (merek) & 2730,467 & 108 & 25,282 & - & - & - \\
\hline Antar & Urutan & 754,533 & 5 & 150,907 & 1,137 & 0,352 & 0,095 \\
subyek & Error Urutan & 7167,333 & 54 & 132,728 & - & - & - \\
\hline
\end{tabular}

Hasil dari pengujian hipotesis adalah sebagai berikut:

a. Pengaruh urutan penyajian terhadap citarasa

Perbedaan urutan menunjukan efek yang tidak signifikan terhadap citarasa $F=1,137 ; p=0,352(p>0,05)$, jadi dapat disimpulkan perbedaan urutan penyajian minuman tidak mempengaruhi persepsi citarasa. Dengan 
demikian, tidak perlu dilakukan post-hoc test untuk mengetahui letak perbedaan persepsi citarasa.

b. Pengaruh citra merek terhadap persepsi citarasa

Merek memberikan pengaruh yang sangat signifikan terhadap citarasa, $F=12,824 ; p<0,001(p<0,01)$, sehingga bila variabel urutan penyajian diabaikan maka pengukuran persepsi citarasa dengan label merek A-one, A-two, dan tanpa merek akan memberikan pengaruh yang berbeda terhadap persepsi citarasa. Berdasarkan hasil penghitungan di atas pengaruh merek memberikan sumbangan sebesar 19,2\% terhadap persepsi citarasa (eta kuadrat $=0,192$ ).

c. Pengaruh interaksi merek dan urutan terhadap persepsi citarasa

Interaksi merek dan urutan memberikan pengaruh yang tidak signifikan terhadap persepsi citarasa, $F=0,619 ; p=0,795$ ( $p>0,05)$. Dengan demikian, dapat dikatakan bahwa pengaruh merek terhadap persepsi citarasa tidak berbeda pada penyajian minuman di awal, tengah, atau paling akhir.

Setelah memenuhi analisis varian, bahwa label merek sangat mempengaruhi persepsi citarasa ( $p<0,001$ ) maka dilakukan pengujian pairwise comparison menggunakan Bonferroni test untuk mengetahui letak perbedaan persepsi citarasa. Bonferroni test dipilih berdasarkan pertimbangan bahwa tes ini dianggap lebih kuat untuk menghitung data yang memiliki sedikit pasangan rerata (Field, 2000). Rangkuman hasil pairwise comparison tersaji dalam Tabel 6.

Tabel 13

Rangkuman Hasil Pairwise Comparison

\begin{tabular}{lll}
\hline Merek & Perbedaan Rerata & p \\
\hline A-one - A-two & 1,617 & 0,092 \\
A-one - Tanpa merek & 4,583 & $\varangle, 001$ \\
A-two - Tanpa merek & 2,967 & 0,007 \\
\hline
\end{tabular}

Hasil perbandingan yang dilakukan antara minuman dengan label A-one dan Atwo menunjukkan $p=0,092$, yang berarti tidak ada perbedaan persepsi citarasa antara minuman dengan label A-one dan A-two. Sementara perbandingan yang dilakukan antara minuman dengan label A-one dan tanpa merek menunjukkan $p<0,001$ yang berarti ada perbedaan persepsi citarasa yang sangat signifikan antara minuman dengan label A-one dan tanpa label merek. 
Berdasarkan perbandingan yang dilakukan antara minuman dengan label A-two dan tanpa merek diperoleh $p=0,007$, yang berarti ada perbedaan persepsi citarasa yang sangat signifikan antara minuman dengan label A-two dan tanpa merek.

Sesuai hasil pengujian hipotesis, ditemukan bahwa merek sangat mempengaruhi persepsi citarasa, sedangkan urutan pemberian minuman tidak memberikan pengaruh terhadap persepsi citarasa. Dapat disimpulkan hipotesis dalam penelitian ini diterima.

\section{Diskusi}

Penelitian ini dilakukan untuk menguji apakah ada perbedaan pengaruh citra merek terhadap persepsi citarasa. Hasil penelitian menunjukkan bahwa terdapat pengaruh citra merek terhadap persepsi citarasa yang sangat signifikan $F=12,824$; $p<$ 0,001 ( $p<0,001$ ). Dengan demikian, hipotesis bahwa terdapat pengaruh citra merek terhadap persepsi citarasa diterima.

Selanjutnya hasil perbandingan skor persepsi citarasa minuman dengan label merek A-one dan tanpa merek menunjukkan ada perbedaan persepsi citarasa antara minuman dengan label merek A-one dan minuman tanpa label merek. Minuman dengan label merek A-one menimbulkan persepsi lebih positif dibandingkan dengan minuman tanpa label merek. Respon tersebut diperlihatkan dengan rerata skor persepsi citarasa minuman yang disajikan dengan label merek $A$-one $(M=52,80)$ lebih tinggi dibandingkan dengan skor yang diberikan pada minuman tanpa label merek ( $M=$ 48,22). Selain itu, hasil perbandingan skor persepsi citarasa antara minuman dengan label merek A-two dan tanpa merek menunjukkan ada perbedaan persepsi citarasa antara minuman dengan label merek A-two dan minuman tanpa label merek. M inuman dengan label merek A-two menimbulkan persepsi lebih positif dibandingkan dengan minuman tanpa label merek.

Respon tersebut diperlihatkan dengan rerata skor persepsi citarasa minuman yang disajikan dengan label merek A-two $(M=51,18)$ lebih tinggi dibandingkan dengan skor yang diberikan pada minuman tanpa label merek $(M=48,22)$. Sementara hasil perbandingan antara skor persepsi citarasa antara minuman dengan label merek A-one dan minuman dengan label merek A-two menunjukkan tidak ada perbedaan persepsi citarasa antara minuman dengan label merek A-one dan minuman dengan label merek A-two. 
Dari uraian di atas, dapat ditarik kesimpulan bahwa ada perbedaan persepsi citarasa antara minuman bermerek dan tanpa merek. Hal ini sesuai dengan hasil penelitian Schultz \& Schultz (1994) bahwa citarasa minuman yang dikemas dalam dua kemasan yang berbeda akan dipersepsi secara berbeda pula. Persepsi citarasa merupakan persepsi yang sulit diidentifikasi dan lebih dipengaruhi oleh faktor-faktor luar, seperti citra yang melekat dalam benak individu (Sulaksana, 2003; Assael, 1998). Oleh karena itu, persepsi citarasa terhadap produk akan dipengaruhi oleh faktor-faktor seperti kemasan produk yang bersangkutan.

Citra merek terbukti mampu mempengaruhi timbulnya persepsi citarasa terhadap produk yang dikemasnya. Hasil ini menunjukkan adanya hubungan antara citra merek dan persepsi citarasa. Hal ini mendukung hasil penelitian Van Osselaer \& Janiszewski (2001), yang menyatakan produk yang menggunakan bahan-bahan bermerek dipersepsi lebih positif daripada produk yang tidak menggunakan bahanbahan bermerek.

Hubungan antara citra merek dan persepsi citarasa timbul karena adanya asosiasi merek. Asosiasi merek adalah segala sesuatu yang berhubungan dengan ingatan terhadap suatu merek, sehingga seseorang dapat membedakan suatu merek dengan merek-merek yang lain (Aaker, 1991). Asosiasi merek dalam ingatan seseorang dapat membentuk persepsi tentang produk atau imej merek di mata mereka.

Contohnya, ketika seseorang ditanya apa merek air mineral dalam kemasan yang paling enak, ia akan menjawab 'A-one', walaupun air tetaplah air. Keller (1998) menyatakan bahwa asosiasi merek merupakan sesuatu yang berhubungan dengan ingatan terhadap merek. Asosiasi ini bisa dikatakan sebagai atribut yang menggambarkan sebuah produk atau jasa sesuai dengan apa yang dipikirkan seseorang (Aryani, 2005). Atribut produk langsung berhubungan dengan penampilan produk. Atribut tidak berkaitan dengan fungsi produk tetapi dengan citra produk (Ismarrahmini \& Brotoharsojo, 2005)

Hasil yang berbeda didapatkan pada minuman dengan label merek yang dicitrakan berkualitas dan kurang berkualitas. Hasil yang didapat menunjukkan tidak ada perbedaan persepsi citarasa antara kedua jenis minuman itu. Hal ini menunjukkan bahwa evaluasi terhadap produk atau konsep lainnya seringkali adalah suatu tanggapan afektif yang lemah, yang diikuti oleh tingkat gerakan yang rendah, bahkan kadangkala seseorang tidak dapat merasakannya sama sekali (Peter \& Olson, 1999). Dalam hal ini terlihat subjek tidak lebih baik dalam mengidentifikasi merek yang biasa mereka konsumsi dengan merek lain. Sebenarnya konsumen sulit membedakan rasa 
merek minuman satu dengan yang lain, citra mereklah yang membuat konsumen memutuskan memilih merek favorit (Solso, Johnson, \& Beal, 1998).

Tidak adanya perbedaan persepsi citarasa antara minuman dengan label merek berkualitas dan tidak berkualitas dapat juga disebabkan pemilihan perwakilan merek yang tidak berimbang. Merek A-two yang dipilih sebagai perwakilan merek tidak berkualitas berada 2 nomer dibawah A-one, yang mewakili merek berkualitas dalam hal top of mind dan tingkatan awareness brand recall konsumen (Santoso, 2005). Sedangkan merek A-one sendiri telah menjadi merek generik. A-one berasal dari bahasa Latin yang berarti air, mengandung arti yang bersifat generic. Pengamat pemasaran dari IBII Consulting, Darmadi Durianto berpendapat bahwa merek A-one sudah terlalu kuat dan konsumen mengasosiasikan merek tersebut sebagai agen dari produk kategori alias generik. Keuntungan dari popularitas merek seperti itu, tingkat awareness-nya sangat tinggi. Tetapi, karena menjadi merek generik, konsumen tidak selektif ketika menerima produk yang diberikan pedagang (Jahari \& Akbar, 2005).

Hasil penelitian Santoso (2005) menunjukkan dalam hal asosiasi konsumen terhadap merek, hasil survey menunjukkan bahwa air minum dalam kemasan A-two mempunyai asosiasi yang sama positifnya jika dibandingkan dengan air minum dalam kemasan merek A-one. Asosiasi responden yang terbanyak pada air mineral dalam kemasan A-two adalah kemasan bagus, diikuti oleh sehat bagi tubuh dan harga murah.

\section{Daftar Pustaka}

Aaker, D. A. (1991). Managing Brand Equity: Capitalizing on The Value of A Brand Name. New York: The Face Press.

Apsari, Y. (2006). Sikap terhadap M erek yang Dikondisikan secara Klasik. Tesis: tidak diterbitkan. Yogyakarta: Fakultas Psikologi Universitas Gadjah Mada.

Aryani, A. (2005). Perbandingan Efektivitas Antara Product Placement dan Iklan. Psikologi Ekonomi \& Konsumen, Juli 2005, 7-28. Bogor: Bagian Psikologi Industri \& Organisasi Universitas Indonesia.

Assael, H. (1998). Consumer Behavior and Marketing Action ( $6^{\text {th }}$ ed) Ohio: South Western College Publishing.

Campbell, D.T \& Stanley, J.C. (1973). Experimental and Quasi-Experimantal Designs for Research. Chicago: Rand M cNally College Publishing Company.

Engel, J.F., Blackwell, R.D., \& M iniard, P.W. (1990). Consumer Behavior. Sixth Edition. Chicago: The Dryden Press.

Field, A. (2000). Discovering Statistic Using SPSS for Windows. London: SAGE Publications. 
Hendriani, L. Rahasia J.CO. Donuts \& Coffee. Majalah M IX. 20 Maret 2006.

Ismarrahmini, U \& Brotoharsojo, H. Pengaruh Kepribadian dan Citra Merek terhadap Loyalitas Konsumen. Psikologi Ekonomi \& Konsumen, Juli 2005, 197-213. Bogor: Bagian Psikologi Industri \& Organisasi Universitas Indonesia.

Jahari, T\& Akbar, R. (2005 ).Aqua ya Aqua. Majalah Marketing, Kompas Cyber M edia. Kharismahayati, P. (2006). Persepsi Citarasa Produk Minuman Kopi Siap Saji dintinjau dari Perbedaan Warna Kemasan. Skripsi: tidak diterbitkan. Yogyakarta: Fakultas Psikologi Universitas Gadjah M ada.

Keller, L. K. (1998). Strategic Brand Management: Building, Measuring and Managing Brand Equity. New Jersey: Prentice Hall.

Kotler, P. (1997). Marketing Management: Analysis, Planning, Implementation, and Control. Ninth Edition. New Jersey: Prentice Hall, Inc.

Peter, P.J \& Olson, J.C. (1999). Consumer Behavior: Perilaku konsumen dan Strategi Pemasaran (terjemahan: Damos Sihombing). Edisi 4. Jakarta: Erlangga.

Purohit, D \& Srivastava, J. (2001). "Effect of Manufacturer Reputation, Retailer, Reputation, and Product Warranty on Consumer Judgement of Product Quality: A Cue Diagnoticity Framework, Journal of Consumer Psychology, 10 (3), 123-134.

Santoso, T. (2005). Analisis brand equity air minum dalam kemasan A-two dibandingkan dengan A-one. Tesis: tidak diterbitkan. Jakarta: M M-FEUI

Schiffman, H.R. (1990). Sensation \& Perception: An Integrated Approach. Third edition. New York: Willey \& Sons.

Schiffman, L.G \& Kanuk, L.L. (2004). Consumer Behavior. Fourth Edition. New Jersey: Prentice-Hall.

Schultz, D. P. \& Schultz, S. E.(1994). Psychology \& Work Today: An Introduction to Industrial \& Organisational Psychology $\left(6^{\text {th }}\right.$ ed). New York: MacMillan Publishing Company.

Sekuler, R \& Blake, R. (1990). Perception. Second Edition. Singapore: McGraw-Hill Book.

Solso, R.L, Johnson, H.H \& Beal, M.K. (1998). Experimental Psychology: A Case Approach. Sixth Edition. New York: Addison Wesley Longman, Inc.

Sulaksana, U. (2003). Integrated Marketing Communication: Teks dan Kasus. Yogyakarta: Pustaka belajar.

Susanta, R. (2006). Air, Tetaplah Air. Kompas Cyber M edia.

Taniardi, P. N. Aris Aris M undayat: "Coffee Shop Menunjukkan Kelas". Ranah, buletin mahasiswa Antropologi UGM. Edisi 3. April 2006.

Van Osselaer, S.M.J \& Alba, J.W. (2000). "Consumer Learning and Brand Equity", Journal of Consumer Research, 28 (September), 202-203.

$\&$ Janizewski, C. (2001). Two Ways of Learning Brand Association, Journal of Personality and Social Psychology, 69 (July), 5-15. 
Wells, W.D. \& Prensky, D. (1996). Conumer Behavior. New York: John Wiley \& Sons. Widyaningrum, F.L. (1997). Hubungan antara Persepsi terhadap Brand Image dan Kualitas Pelayanan terhadap Perilaku Ulang Pengambilan Kredit pada Perum Pegadaian. Skripsi: tidak diterbitkan. Yogyakarta: Fakultas Psikologi Universitas Gadjah Mada. 